\title{
Apresentação do livro "Taxonomic Revision of the Neotropical Tiger Beetle Genera of the Subtribe Odontocheilina (Coleoptera: Cicindelidae)", Volume 1 e 2, de autoria de Jiří Moravec e publicados pela "Biologická Rezervace Dolní Morava"
}

\author{
André Silva Roza ${ }^{1,2} \mathbb{C}$
}

(1) Universidade Federal do Rio de Janeiro, Instituto de Biologia, Departamento de Zoologia, Laboratório de Entomologia, A1-107, Bloco A, Av. Carlos Chagas Filho 373, Cidade Universitária 21941-599, Ilha do Fundão, Rio de Janeiro, Brasil. E-mail: andreroza1993@gmail.com

(2) Universidade Federal do Rio de Janeiro, Museu Nacional do Rio de Janeiro, Programa de Pós-Graduação em Zoologia, Parque Quinta da Boa Vista, Mangueira 20940-040, Rio de Janeiro, Brasil.

Roza A.S. (2021) Apresentação dos livros "Taxonomic revision of the Neotropical tiger beetle genera of the subtribe Odontocheilina (Coleoptera: Cicindelidae)", Volume 1 e 2, de autoria de Jiří Moravec e publicados pela Biologická Rezervace Dolní Morava. Pesquisa e Ensino em Ciências Exatas e da Natureza, 5: e1661.

http://dx.doi.org/10.29215/pecen.v5i0.1661

Editor acadêmico: Silvio F. B. Lima. Recebido: 28 fevereiro 2021. Aceito: 01 março 2021. Publicado: 08 março 2021.

Resumo: Apresentamos os livros "Taxonomic Revision of the Neotropical Tiger Beetle Genera of the Subtribe Odontocheilina (Coleoptera: Cicindelidae)", Volume 1 e 2, de autoría de Jiř́ Moravec, onde existem redescrições, ilustrações de alta qualidades, chaves de identificação e mapas de distribuição de uma das maiores subtribos de Besouros tigre neotropicais.

Palavras chave: Besouros tigre, distribuição, Odontocheilina, revisão.

Book presentation of "Taxonomic Revision of the Neotropical Tiger Beetle Genera of the Subtribe Odontocheilina (Coleoptera: Cicindelidae)", Volume 1 e 2, authored by Jiří Moravec and published by Biologická Rezervace Dolní Morava

Abstract: We present the books "Taxonomic Revision of the Neotropical Tiger Beetle Genera of the Subtribe Odontocheilina (Coleoptera: Cicindelidae)", Volume 1 and 2, authored by Jiři Moravec, where there are redescriptions, high-quality illustrations, identification keys and distribution maps of one of the largest subtribes of neotropical tiger beetles.

Key words: Tiger beetles, distribuition, Odontocheilina, revision. 
Besouros-tigre são um famoso grupo de besouros, conhecidos pelas suas cores brilhantes e comportamento distintos. Todos os membros de Cicindelidae são predadores vorazes e extremamente rápidos quando adultos, e predadores de tocaia quando larvas. Esse grupo de besouros está entre os mais bem estudados do mundo, com uma grande quantidade de conhecimento acumulado durante o último século e o início deste (e.g., Pearson 1988; Serrano 2000; Pearson \& Vogler 2001; Erwin \& Pearson 2008). Apesar disso, uma grande quantidade de espécies continua sendo descrita anualmente (e.g., Duran \& Moravec 2013; Moravec \& Brzoska 2013; Moravec 2016b; Moravec et al. 2017a), especialmente nas regiões Neotropical e Oriental, e o status de conservação de várias espécies, junto de suas distribuições, ainda não são muito conhecidas (e.g., Roza \& Mermudes 2015, 2017). Existe uma longa tradição de se publicar, além de artigos em periódicos, livros e guias de identificação para os Besouros-tigre em diversos lugares do mundo, principalmente nos Estados Unidos e na Europa (e.g., Trautner \& Geigenmueller 1987; Pearson et al. 2015). Essa tradição, no entanto, não é comum na América Latina. Com a exceção de Erwin \& Pearson (2008), livro que trata de todos os Cicindelidae do Hemisfério Oeste, nenhum outro livro apresenta chaves de identificação ou ilustrações detalhadas de espécies da região.

Essa situação, no entanto, pode estar para mudar. Com a publicação de Moravec (2018b) e Moravec (2020) (Taxonomic Revision of the Neotropical Tiger Beetle Genera of the Subtribe Odontocheilina (Coleoptera: Cicindelidae), Volume 1 e 2, respectivamente), a América Latina passa a ter um guia de identificação e revisão taxonômica para cada espécie da subtribo Odontocheilina W. Horn 1899 sensu Moravec (2012a), uma das mais diversas em números de espécies para a região, com 15 gêneros e 171 espécies. Ambos os livros tem uma apresentação semelhante, com a parte introdutória constituída do material e métodos, taxonomia e nomenclatura, comentários sobre filogenia, estágios de de-
Tiger beetles are a famous group of beetles, known for their bright colors and distinct behavior. All members of Cicindelidae are voracious predators and extremely fast as adults, and ambush predators when larvae. This group of beetles is among the best studied in the world, with a great deal of knowledge accumulated during the last century and the beginning of the currently one (e.g., Pearson 1988; Serrano 2000; Pearson \& Vogler 2001; Erwin \& Pearson 2008). Despite this, a large number of species continues to be described annually (e.g., Duran \& Moravec 2013; Moravec \& Brzoska 2013; Moravec 2016b; Moravec et al. 2017a), especially in the Neotropical and Eastern regions, and the conservation status of several species, together with their distributions, are not yet well known (e.g., Roza \& Mermudes 2015, 2017). There is a long tradition of publishing, in addition to articles in journals, books and identification guides for tiger beetles in different parts of the world, mainly in the United States and Europe (e.g., Trautner \& Geigenmueller 1987; Pearson et al. 2015). This tradition, however, is not common in Latin America. With the exception of Erwin \& Pearson (2008), a book that deals with all Cicindelidae in the Western Hemisphere, no other book presents identification keys or detailed illustrations of species in the region.

This situation, however, may be about to change. With the publication of Moravec (2018b) and Moravec (2020) (Taxonomic Revision of the Neotropical Tiger Beetle Genera of the Subtribe Odontocheilina (Coleoptera: Cicindelidae), Volume 1 and 2, respectively), Latin America now has an identification guide and taxonomic revision for each species of the subtribe Odontocheilina W. Horn 1899 sensu Moravec (2012a), one of the most diverse in number of species for the region, with 15 genera and 171 species. Both books have a similar presentation, with the introductory part consisting of the material and methods, taxonomy and nomenclature, comments on phylogeny, stages of development, biology and distribution, and adult morphology. The main part of the bo- 
senvolvimento, biologia e distribuição, e morfologia dos adultos. A parte principal do livro trata da revisão sistemática dos gêneros da subtribo, apresentando chaves de identificação para os gêneros de Odontocheilina e para todas as espécies de cada gênero. Além disso é apresentada a descrição e diagnose de cada gênero, subgênero e espécies, as últimas acompanhadas de fotografias de alta qualidade mostrando os espécimes da sérietipo e suas etiquetas, além de vários espécimes que compreendem a variação morfológica e cromática de cada espécie. Também são apresentados mapas de distribuição para cada espécie revisada. Ambos os livros são o resultado de 10 anos de estudos no grupo pelo autor.

O livro também apresenta mudanças taxonômicas e indicações de lectótipos e neótipos. Muitas mudanças apresentadas já foram feitas anteriormente em uma série de artigos publicados pelo autor, por vezes acompanhado de outros colegas, onde a revisão da subtribo foi sendo construída aos poucos, gênero por gênero, espécie por espécie (e.g., Moravec \& Kudrna 2002; Moravec 2012a,b,c, 2013, 2014, 2015a,b,c, 2016a,b,c, 2017, 2018a,b, 2019; Duran \& Moravec 2013; Moravec \& Brzoska 2013, 2014a,b,c, 2015, 2019; Moravec \& Duran 2013; Moravec \& Huber 2015; Moravec et al. 2015, 2017a,b). Entretanto, os livros, além de apresentar novas mudanças e chaves inéditas para espécies de alguns gêneros, reúne toda a informação conhecida para Odontocheilina e apresenta de forma organizada e graficamente impecável.

$\mathrm{O}$ primeiro volume trata de 87 espécies dentro do grande e complexo gênero Odontocheila Laporte de Castelnau, 1834 (78 espécies), além dos menores Cenothyla Rivalier, 1969 (7 espécies) e Phyllodroma Lacordaire, 1842 (2 espécies). Já o segundo volume trata das 84 espécies restantes da subtribo, dentro dos gêneros Mesochila Rivalier, 1969 (20 espécies), Poecilochila Rivalier, 1969 (11 espécies), Beckerium W. Horn, 1897 (1 espécie), Brzoskaicheila Moravec, 2012 (2 espécies), Ronhuberia Moravec \& Kudrna, 2002 (2 espécies), Mesacanthina Rivalier, 1969 (9 es- ok deals with the systematic review of the subtribe genera, presenting identification keys for the Odontocheilina genera and for all species of each genus. In addition, the description and diagnosis of each genus, subgenus and species is presented, the latter accompanied by high quality photographs showing the specimens of the type-series and their labels, in addition to several specimens that comprise the morphological and chromatic variation of each species. Distribution maps for each revised species are also presented. Both books are the result of 10 years of study in the group by the author.

The book also presents taxonomic changes and indications of lectotypes and neotypes. Many changes presented have already been made previously in a series of articles published by the author, sometimes accompanied by other colleagues, where the revision of the subtribe was gradually being constructed, genus by genus, species by species (e.g., Moravec \& Kudrna 2002; Moravec 2012a,b,c, 2013, 2014, 2015a,b,c, 2016a,b,c, 2017, 2018a,b, 2019; Duran \& Moravec 2013; Moravec \& Brzoska 2013, 2014a,b,c, 2015, 2019; Moravec \& Duran 2013; Moravec \& Huber 2015; Moravec et al. 2015, 2017a,b). However, the books, in addition to presenting new changes and new keys for species of some genera, gather all the information known to Odontocheilina and present it in an organized and graphically impeccable way.

The first volume deals with 87 species within the large and complex Odontocheila Laporte de Castelnau genus, 1834 (78 species), in addition to the smaller Cenothyla Rivalier, 1969 (7 species) and Phyllodroma Lacordaire, 1842 (2 species). The second volume, on the other hand, deals with the 84 remaining species of the subtribe, within the genera Mesochila Rivalier, 1969 (20 species), Poecilochila Rivalier, 1969 (11 species), Beckerium W. Horn, 1897 (1 species), Brzoskaicheila Moravec, 2012 (2 species), Ronhuberia Moravec \& Kudrna, 2002 (2 species), Mesacanthina Rivalier, 1969 (9 espécies), Opisthencentrus W. Horn, 1893 (1 species), Pentacomia Bates, 1892 (12 species), Cheilonycha Lacordaire, 1842 (3 species), 
pécies), Opisthencentrus W. Horn, 1893 (1 espécie), Pentacomia Bates, $1892 \quad$ (12 espécies), Cheilonycha Lacordaire, 1842 (3 espécies), Pometon Fleutiaux, $1899 \quad$ (2 espécies), Eulampra Chaudoir, 1848 (1 espécie) e Oxygonia Mannerheim, 1837 (20 espécies). Os dois livros representam o fim do impedimento taxonômico para um dos maiores grupos de besouros-tigre neotropicais, e é essencial na biblioteca de qualquer coleopterólogo interessado em trabalhar com Cicindelidae.

\section{Referências / References}

Duran D.P. \& Moravec J. (2013) A new species of the genus Pentacomia from Panama (Coleoptera: Cicindelidae). Acta Entomologica Musei Nationalis Pragae, 53: 49-57.

Erwin T.L. \& Pearson D.L. (2008) A Treatise on the Western Hemisphere Caraboidea (Coleoptera), Their Classification, Distributions, and Ways of Life. Volume II. Carabidae - Nebriiformes 2 - Cicindelitae. Pensoft, Sofia: Pensoft Series Faunistica 84. $365 \mathrm{p}$.

Moravec J. (2012a) Taxonomic and nomenclatorial revision within the Neotropical genera of the subtribe Odontochilina in a new sense - 1 . Some changes in taxonomy and nomenclature within the genus Odontocheila (Coleoptera: Cicindelidae). Acta Musei Moraviae, Scientiae Biologicae, 97(2): 1333.

Moravec J. (2012b) Taxonomic and nomenclatorial revision within the Neotropical genera of the subtribe Odontochilina W. Horn in a new sense -2 . Brzoskaicheila gen. nov., a new genus for Cicindela hispidula Bates, 1872, and Brzoskaicheila crassisculpta sp. nov. (Coleoptera: Cicindelidae). Acta Musei Moraviae, Scientiae Biologicae, 97(2): 3548.

Moravec J. (2012c) Taxonomic and nomenclatorial revision within the Neotropical genera of the subtribe Odontochilina W. Horn in a new sense -3 . Pentacomia (Mesacanthina) punctum (Klug) and P. (M.) ronhuberi sp. nov. (Co-
Pometon Fleutiaux, 1899 (2 species), Eulampra Chaudoir, 1848 (1 species) e Oxygonia Mannerheim, 1837 (20 species). Both books represent the end of the taxonomic impediment for one of the largest groups of neotropical tiger beetles, and are essential in the library of any coleopterist interested in working with Cicindelidae.

leoptera: Cicindelidae). Acta Musei Moraviae, Scientiae Biologicae, 97(2): 4963.

Moravec J. (2013) Taxonomic and nomenclatorial revision within the Neotropical genera of the subtribe Odontocheilina W. Horn in a new sense 4. A new species and a new synonymy within the genus Odontocheila. (Coleoptera: Cicindelidae). Acta Musei Moraviae, Scientiae Biologicae, 98(1): 5373.

Moravec J. (2014) Taxonomic and nomenclatorial revision within the Neotropical genera of the subtribe Odontocheilina W. Horn in a new sense 9. Odontocheila pentacomioides W. Horn, 1900 comb. restit.; $O$. cyanella pseudomargineguttata W. Horn, 1930 syn. nov., a junior synonym of $O$. spinipennis Chaudoir, 1843. Acta Musei Moraviae, Scientiae Biologicae (Brno), 99(1): 47-64.

Moravec J. (2015a) Taxonomic and nomenclatorial revision within the Neotropical genera of the subtribe Odontochilina W. Horn in a new sense 11. The genus Cenothyla Rivalier, 1969 (Coleoptera: Cicindelidae). Studies and Reports Taxonomical Series, 11(1): 77-122.

Moravec J. (2015b) Taxonomic revision within the Neotropical genus Oxygonia Mannerheim - $\quad 1 \quad$ (Coleoptera: Cicindelidae). Folia Heyrowskyana, Series A 23(2): 27-70.

Moravec J. (2015c) Case 3698 Cicindela varians Gory, 1833 (currently Cenothyla varians; Coleoptera, Carabidae): proposed 
conservation. The Bulletin of Zoological Nomenclature, 72(4): 288-290.

Moravec J. (2016a) Taxonomic and nomenclatorial revision within the Neotropical genera of the subtribe Odontochilina W. Horn in a new sense 15. The genus Opisthencentrus W. Horn, (Coleoptera: Cicindelidae). Zootaxa, 4097(3): 332-340.

Moravec J. (2016b) Taxonomic and nomenclatorial revision within the Neotropical genera of the subtribe Odontocheilina W. Horn in a new sense 16. Pentacomia (Mesochila) procera (Chaudoir), P. (M.) conformis (Dejean), and $P$. (M.) proceroides sp. nov. (Coleoptera: Cicindelidae). Zootaxa, 4127(2): 276-300.

Moravec J. (2016c) Taxonomic and nomenclatorial revision within the Neotropical genera of the subtribe Odontocheilina W. Horn in a new sense 17. O. cajennensis species-complex and key to species of Odontocheila cajennensis species-group (Coleoptera: Cicindelidae). Acta Musei Moraviae, Scientiae Biologicae (Brno), 101(1): 7-53.

Moravec J. (2017) Taxonomic revision within the Neotropical genus Oxygonia Mannerheim - 2 (Coleoptera: Cicindelidae). Folia Heyrowskyana, Series A, 25(2): 31-122.

Moravec J. (2018a) Taxonomic and nomenclatorial revision within the Neotropical genera of the subtribe Odontocheilina W. Horn in a new sense 20. Beckerium W. Horn stat. restit., Mesochila Rivalier stat. nov. and Poecilochila Rivalier stat. nov. Acta Musei Moraviae, Scientiae Biologicae (Brno), 103(2): 127-206.

Moravec J. (2018b) Taxonomic revision of the Neotropical tiger beetle genera of the subtribe Odontocheilina - Volume 1. Odontocheila Laporte de Castelnau, Cenothyla Rivalier and Phyllodroma Lacordaire (Coleoptera: Cicindelidae). Biosférická rezervace Dolni Morava, o.p.s., Lednice na Moravê. $623+2 \mathrm{p}$.

Moravec J. (2019) Taxonomic and nomenclatorial revision within the Neotropical genera of the subtribe Odontocheilina W. Horn in a new sense -
22. Genus Cheilonycha Lacordaire, 1842 (Coleoptera: Cicindelidae). Zootaxa, 4700(4): 501-534.

Moravec J. (2020) Taxonomic revision of the Neotropical tiger beetle genera of the subtribe Odontocheilina - Volume 2. A complete revision of other twelve genera of the subtribe (Coleoptera: Cicindelidae). Biosférická rezervace Dolni Morava, o.p.s., Lednice na Moravê. 591+2 p.

Moravec J. \& Brzoska D. (2013) Taxonomic and nomenclatorial revision within the Neotropical genera of a subtribe Odontochilina W. Horn in a new sense -5 . A new species of the genus Pentacomia from Costa Rica (Coleoptera: Cicindelidae). Acta Musei Moraviae, Scientiae Biologicae (Brno), 98(1): 75-84.

Moravec J. \& Brzoska D. (2014a) Taxonomic and nomenclatorial revision within the Neotropical genera of the subtribe Odontocheilina W. Horn in a new sense 7. Pentacomia (Pentacomia) davidpearsoni sp. nov., a new species from Bolivia related to $P$. (P.) speculifera (Brullé) (Coleoptera: Cicindelidae). Acta Musei Moraviae, Scientiae Biologicae (Brno), 99(1): 15-33.

Moravec J. \& Brzoska D. (2014b) Taxonomic and nomenclatorial revision within the Neotropical genera of the subtribe Odontocheilina W. Horn in a new sense 8. Redescription and lectotype designation of Pentacomia (Pentacomia) lanei (W. Horn), with a new record from Paraguay. Acta Musei Moraviae, Scientiae Biologicae (Brno), 99(1): 35-46.

Moravec J. \& Brzoska D. (2014c) Taxonomic and nomenclatorial revision within the Neotropical genera of the subtribe Odontocheilina W. Horn in a new sense 10. Odontocheila castelnaui species-group (Coleoptera, Cicindelidae). Studies and Reports Taxonomical Series, 10(2): 495526.

Moravec J. \& Brzoska D. (2015) Taxonomic and nomenclatorial revision within the Neotropical genera of the subtribe Odontocheilina W. Horn in a new sense 12. Odontocheila angelsolisi sp. nov., $O$. mirekskrabali sp. nov. and related species of a newly proposed Odontocheila cajennensis species-group (Coleoptera: 
Cicindelidae). Acta Musei Moraviae, Scientiae biologicae (Brno), 100(1): 23-66.

Moravec J. \& Brzoska D. (2019) Taxonomic and nomenclatorial revision within the Neotropical genera of the subtribe Odontocheilina W. Horn in a new sense 21. Pentacomia paranigrimarginata sp. nov. and $P$. nigrimarginata Huber with revised key to Pentacomia species (Coleoptera: Cicindelidae). Zootaxa, 4612(1): 71-84.

Moravec J., Brzoska D. \& Huber R.L. (2017a) Taxonomic and nomenclatorial revision within the Neotropical genera of the subtribe Odontocheilina W. Horn in a new sense - 18. Six Mexican and Central American species related to Odontocheila mexicana Laporte de Castelnau and $O$. ignita Chaudoir, with a description of $O$. potosiana sp. nov. (Coleoptera: Cicindelidae). Zootaxa, 4231(4): 451-499.

Moravec J. \& Duran D.P. (2013) Taxonomic and nomenclatorial revision within the Neotropical genera of the subtribe Odontochilina. - 6 . Odontocheila fraternum sp. nov., a new species sister to O. gilli (Coleoptera: Cicindelidae). Acta Entomologica Musei Natioalis Pragae, 53: 585-599.

Moravec J. \& Huber R.L. (2015) Taxonomic and nomenclatorial revision within the Neotropical genera of the subtribe Odontocheilina W. Horn in a new sense œ 13. The genus Mesacanthina Rivalier, stat. nov., separated from the genus Pentacomia Bates (Coleoptera: Cicindelidae). Acta Musei Moraviae, Scientiae biologicae (Brno), 100(1): 67-114. Moravec J., Huber, R.L. \& Brzoska D. (2017b) Taxonomic and nomenclatorial revision within the Neotropical genera of the subtribe Odontocheilina W. Horn in a new sense - 19. Odontocheila microptera nom. nov., a new replacement name for $O$. euryoides W. Horn, 1922, and lectotype designation of $\boldsymbol{O}$. nitidicollis (Dejean, 1825) (Coleoptera: Cicindelidae). Zootaxa, 4347(1): 109-127.

Moravec J., Huber R.L. \& Dheurle C. (2015) Taxonomic and nomenclatorial revision within the Neotropical genera of the subtribe Odontocheilina W. Horn in a new sense n 14. Pentacomia (Pentacomia) chrysammoides sp. nov., a new species related to $P$. (P.) chrysamma (Coleoptera: Cicindelidae). Acta Musei Moraviae, Scientiae Biologicae (Brno), 100(2): 217249.

Moravec J. \& Kudrna A. Jnr. (2002) Ronhuberia gen. n. with type species Pentacomia fernandezi (Cassola) comb. n.; $R$. eurytarsipennis (W. Horn) comb. $\mathrm{n}$. Cicindela, 34(3-4): 17-37.

Pearson D.L. (1988) Biology of tiger beetles. Annual Review of Entomology, 33: 123147.

Pearson D.L. \& Vogler A.P. (2001) The Evolution, Ecology and Diversity of the Cicindelids. Tiger Beetles. Ithaca: omstock Publishing Associates, Cornell University Press. 352 p.

Pearson D.L., Knisley C.B., Duran D.P. \& Kazilek C.J. (2015) A Field Guide to the Tiger Beetles of the United States and Canada: Identification, Natural History, and Distribution of the Cicindelinae. Oxford: Oxford University Press. 328 p.

Roza A.S. \& Mermudes J.R.M. (2015) Description of the immature stages of Pentacomia (Mesochila) smaragdula (Dejean, 1825) (Coleoptera: Carabidae, Cicindelinae), with notes on the species distribution. Zootaxa, 4057(3): 399-408.

Roza A.S. \& Mermudes J.R.M. (2017) Distribution of Pentacomia (Mesochila) Rivalier, 1969 (Coleoptera: Carabidae, Cicindelinae). Transactions of the American Entomological Society, 143(3): 601-623.

Serrano A.R.M. (2000) Are tiger beetles (Coleoptera: Cicindelidae) well studied? A myth or a reality? (p. 69-90) In: Sobti R.C. \& Yadav J. (Orgs). Some Aspects on the Insight of Insect Biology. Delhi: Narendra Publishing House. 316 p.

Trautner J. \& Geigenmüller K. (1987) Tiger beetles, ground beetles. Illustrated key to the Cicindelidae and Carabidae of Europe. Alemanha: TRIOPS Verlag. 487 p. 